\title{
A Mobile Video Recording Task-Based Approach to Teaching EFL Learners' Speaking Skills
}

\author{
Tran Thi Thien Trang, Nguyen Thi Phuong Hong \\ Can Tho University, Vietnam
}

\begin{abstract}
The purpose of this paper was to investigate whether mobile video recording task-based approach helps non-English majored students enhance their speaking skills. Forty students were selected and assigned to two groups: experimental group and control group. Mobile video recording was presented to experimental students while no training was given to students in the control group in the same task-based approach. The data was assessed to find out whether there were significant differences in terms of fluency, grammar, vocabulary and pronunciation. A questionnaire and a semi-structured interview were also implemented to explore students' attitudes on the treatment. The study's results revealed that students in the group treated with mobile video recording task-based approach significantly outperformed those in the control group. Furthermore, the results of the questionnaire and semi-structured interview revealed that the experimental students had positive attitudes towards using mobile video recording to practice speaking English. The study's findings have led to several ideas and recommendations for the teachers, the students as well as the teaching and learning speaking in Vietnam.
\end{abstract}

Keywords: mobile-assisted language learning, video recordings, task-based approach, speaking performance, speaking skills

\section{Introduction}

Speaking skills is one of the language skills that have to be mastered by students. Maryam and Reza (2014) defined that speaking is one of the students' abilities that mostly will be assessed in the real-world context. However, students have some difficulties in improving their speaking skills. Firstly, it is not easy for learners to find a supporting environment to train their speaking skill. As a result, they only practice speaking English inside the class with a limited time. Secondly, the goal of learning to speak is not obvious because students live in an environment in which speaking English is not necessary. Therefore, they do not have strong motivation to train their speaking skill in order to use the language properly. Thirdly, there are some constraints of speaking English. Some people reveal that they have no idea what they are going to say, they have lack of preparation, they are shy and worried about getting wrong or have less confidence. Then as the response to those problems and the importance of speaking skill, there has been some studies conducted. Among those studies, the study dealing with mobile video recording is interesting to be examined.

As for a pedagogy context in Vietnam normally and in Can Tho City specifically, applying mobile video recording task-based approach to reinforce learners' speaking skill has not been applied widely in schools likewise as English language centers. Moreover, not many researchers are done in this field. Therefore, supporting the reason for the matter in speaking and therefore the emergence of technology, this research is allotted to determine to what extent mobile video recording task-based approach affects students' speaking ability. The researcher also provides teachers a chance to contribute their voices into solutions to reduce the barriers and because the application of mobile video is easier for oral performance. 
DOI: $\underline{10.51386 / 25815946 / \mathrm{ijsms}-\mathrm{v} 4 \mathrm{i} 4 \mathrm{p} 111}$

\section{Literature review}

\subsection{Speaking skills}

Speaking skill is a practical skill which learners may explain, justify, and pass their thoughts and ideas. Besides, speaking skill is defined as generating utters, phrases and sentences in conjunction with carrying messages for different purposes by utilizing the correct grammatical rules and vocabulary together with the soul of confidence and convenience (Ashour, 2014). Among several definitions of speaking skills, (Chaney \& Burk, 1998) defined speaking as "the process of building, and sharing meaning through the use of verbal and non-verbal symbols in a variety of contexts.". Speaking is also described as "the practice of constructing and communicating sense by the use of verbal and nonverbal representations in many ways." Speaking is described as it is the mastery of grammatical form, vocabulary, and cultural expectations, pronunciations, stress, and intonation in authentic communication functions (Durkheim, 1956). Most definitions talk about the wider view of speaking skill and its connection with the cultural background of speakers.

\subsection{Mobile-Assisted Language Learning (MALL)}

The type of language learning which integrates mobile technology as the media of learning is usually called MALL (Mobile-Assisted Language Learning). This is the effect of the rapid growth of technology to pedagogical areas especially in language learning. It is caused by the continuous interaction of students with technology, such as mobile phones, internet, and computers. Even students pay great attention to mobile phones as they can play music and games, send and receive messages, engage in social-media, and use cameras for taking pictures or videos. Moreover, the access to get the device is easier since it is available at many places with various types and prices which can be adjusted based on their need and capability. Therefore, the changing of this life-style makes possible the immersion of technology for language teaching (Richards, 2008).

\subsection{Video Recording}

Video recording is the media which is used in teaching speaking by recording the students' speaking performances. Video recording has the ability to self-reflect and it is widely recognized as the desirable learner attribute that can include the deep learning (Chau and Cheng, 2009). Odhabu\& Nicks-McCaleb (2009) say that media technologies allowed the users to record audio and video by using video cameras in lecture halls and other learning environments. Dali (2012) argues that video recording is favorably perceived media especially in providing feedback. The use of video-recording on students' speaking in language learning offers several advantages: First, students can watch and see themselves and their fellow friends' performances. Second, teachers can use video to help students become better speakers in English (Lonergan, 1984; Tomalin\&Stempleski, 1990). In addition, students have the opportunity to view the recording on video more than once. Thus, recording students' speaking performances allowed the teachers or the students to play and replay the video recording in many times. Hence, the students did self-evaluation of themselves as well as their fellow friends. As a consequence, the students became self-critical, because they can see their problems and trace their improvements. And when the video recording showed to many people, there were some recommendations and suggestions to the presenter.

Video recording allows learners to become the central player in the whole process. This is because learners can view their own performance and compare to a list of criteria, to model performance, or to their own previous performances on a similar task to reflect on strengths and weaknesses and to set a goal for future improvement (Christianson \& Hoskins, 2009).

\subsection{Task-based approach}

The word task is from Old North French 'tasque' which means duty, tax or piece of work imposed as a duty. The Cambridge Advanced Learner's Dictionary (1995, cited by Little wood, 2004) in the article defines a task as a piece of work to be done especially one done regularly. Regarding definitions from trustworthy writers, 
DOI: $\underline{10.51386 / 25815946 / \mathrm{ijsms}-\mathrm{v} 4 \mathrm{i} 4 \mathrm{p} 111}$

Volume: 4 Issue: 4

July to August 2021

https://www.ijsmsjournal.org

Prabhu (1987) considers a task is an activity which required learners to arrive at an outcome from given information through some process of thought, and which allowed teachers to control and regulate that process. Lee (2000) defines a task as (1) a classroom activity or exercise that has: (a) an objective obtainable only by interaction among participants, (b) a mechanism for structuring and sequencing interaction, and (c) a focus on meaning exchange; (2) a language learning endeavor that requires learners to comprehend, manipulate, and/or produce the target language as they perform some sets of work plans. Bygate, Skehan, and Swain (2001) view the task as an activity that requires learners to use language, with emphasis on meaning, to attain an objective.

Task-based Approach (TBA) is also called Task-based Instruction (TBI) or Task-based Language Teaching (TBLT) was born out of "Bangalore Project" that started in 1979 and ended in 1984 by Prabhu in India from the aspect of teaching, stressing that students study languages by fulfilling the tasks in the process of language use. It has caught a lot of attention from educators and scholars in the Second Language Acquisition (SLA) since then. According to Jack (2001), Task-Based Language Teaching (TBLT) refers to an approach based on the use of tasks as the core unit of planning and instruction in language teaching. Skehan (1996), a well-known British linguist, defined TBI as "Instruction in which learners are given tasks to complete in the classroom makes the assumption that transacting tasks in this way will engage naturalistic acquisition mechanisms, cause the underlying inter-language system to be stretched, and drive development forward" ( $p$. 95). Willis (1996) thinks that Task-based Language Teaching (TBLT) is an effective method to English learning and teaching which takes advantage of tasks assigning language learners in a given context and encourages them to finish those tasks for the purpose of communication.

\section{The study}

\subsection{Research design}

The current research follows a descriptive design in which the features of both quantitative and qualitative methods were employed. The descriptive method was chosen with the purpose to establish the existence of phenomena through explicit description (Seliger and Shohamy, 1989). Furthermore, the method provides essential knowledge about the nature of objects or persons (Calmorin L.P and Calmorin M.A, 2001). The descriptive study using a mixed-method was employed to investigate the effects of mobile video recording taskbased approach on EFL learners' speaking performance and EFL learners' attitudes towards the use of mobile video recording as a tool to practice speaking skill. According to Frankel, Wallen and Hyun (2012), a mixedmethod approach incorporates both quantitative and qualitative methods of data collection and analysis.

\subsection{Participants}

\section{Participants for the speaking test}

- The researcher was in charge of instructing lessons to both experimental group and control group.

- The participants of the study were 40 EFL learners from university, colleges or vocational Training School in Can Tho City. They were randomly divided into two groups (control and experimental group; each class consist of 20 learners). Besides, 27 of them were female while 13 of them were male with an age range of 18 to 22. They had a basic level of proficiency in English. The major of the learners were Computer, Mining and Electronic Engineering, International Relations, Business Administration, Doctor and Pharmacist. They had similar backgrounds concerning economic, cultural, and social levels. All of them had been learning English as a foreign language for approximately 8 years and none of them had studied abroad in an English-speaking country. To control the age variable before the application the experiment, the researcher recorded the students' ages before undertaking the tests at beginning of the year (2020-2021). The average age of students was 19 years.

- There are two raters with five years' experience in both teaching and assessing speaking skills, especially IELTS were involved in the assessment procedure together with the teacher researcher. 
DOI: $\underline{10.51386 / 25815946 / \mathrm{ijsms}-\mathrm{v} 4 \mathrm{i} 4 \mathrm{p} 111}$

Volume: 4 Issue: 4

July to August 2021

https://www.ijsmsjournal.org

\section{Participants for the questionnaires}

Twenty EFL learners from experimental group were selected to do the questionnaires. Of this sample, 13 learners $(65 \%)$ were female and 7 learners $(35 \%)$ were male.

\section{Participants for the semi-structured interviews}

Six participants who had been already done the questionnaires were invited to participate in the interview. Additionally, six participants were two the students improved the most, the two students improve the least and the last two improve a little. Two of them are male learners.

\subsection{Research instruments}

\subsubsection{Speaking Test}

In order to determine the impact of mobile video recording on EFL learners' oral performance, the speaking module of IELTS was modified as pre- and post-test. The aim of the IELTS speaking test is to provide accurate scores before and after implementing the mobile video recording to improve speaking skills. Moreover, the test followed what students learn from "The best preparation for IELTS Speaking" written by Young Kim, so it is suitable for students to test their speaking ability.

The IELTS test is produced by British Council. It is designed to assess learners' speaking skills and their ability to communicate in spoken English in the context of a real-life situation. The test is composed of three parts and takes approximately between 11 to 14 minutes to complete. It is designed to provide information about language ability to speakers across a range of language proficiency tests.

The study used the IELTS Evaluation Rubrics to assess students' speaking skills for the oral test in order to achieve the purpose of the research. The analysis sample involved the sub-skills of these aspects (Fluency and Coherence (FC), Lexical Resource (LR), Pronunciation (P), Grammatical Range and Accuracy (GRA) in the IELTS test. These scales are rated into 9 bands. The examiner should rate the students to their real level from 1-9. Appendix (2) shows the IELTS Speaking Band Description that the researcher built the assessment of students' performance on. The table presents a detailed description of each score and how learners can be assessed based on the criteria and performance they made in their tests.

\subsubsection{Questionnaires}

The questionnaire, comprising 35 Likert items, was divided into 2 main sections, regardless of the first section of the participants' personal information. The second section including fifteen items of one cluster that investigated EFL learners' attitudes towards using mobile video recording to practice speaking skills based on the conceptual framework and definitions from the literature review. The participants were asked to give their opinions on the statements based on format of a five-level Likert item ranging from Strongly Disagree (1), Disagree (2), Neutral (3), Agree (4), and Strongly Agree (5). The third section which consisted of twenty items was classified into 2 clusters, namely Benefits and Challenges. This section also used the five-point Liker-scale of the level of agreement ranging from Strongly Disagree (1), Disagree (2), Neutral (3), Agree (4), and Strongly Agree (5) was used to investigate EFL learners' attitudes towards the benefits and drawbacks of using mobile video recording to practice speaking skills.

\subsubsection{Semi-structured interviews}

Semi-structured interviews include several planned questions, but the interviewer has more freedom to modify the wording and order of questions. Interview questions were designed based on the literature review and the content of the questionnaire. Eight questions in the interview were classified into four themes including (1) EFL learners' attitudes towards the employment of using mobile video recording to practice speaking skills; (2) EFL learners' attitudes towards the benefits of using mobile video recording; (3) EFL learners' attitudes towards the 
DOI: $\underline{10.51386 / 25815946 / \mathrm{ijsms}-\mathrm{v} 4 \mathrm{i} 4 \mathrm{p} 111}$

Volume: 4 Issue: 4

July to August 2021

https://www.ijsmsjournal.org

challenges of using mobile video recording and (4) EFL learners' recommendation of using mobile video recording.

\subsection{Data analysis method}

\subsubsection{Analysis 1: Students' speaking performance before and after the intervention}

To analyze the quantitative date, the computer Statistical Package for the Social Sciences (SPSS) version 20 was employed. First, the internal consistency reliability was assessed to check the reliability of the speaking test results. Second, in order to ensure valid and reliable scoring, a second and third rater with five years' experience in both teaching and assessing speaking skills were involved in the assessment procedure together with the teacher researcher. The second and the third rater also worked as an instructor in the same English center with the researcher and both raters had the formal training on the use of the IELTS speaking scale. Third, a Descriptive Statistics Test was run to examine mean score from 2 groups (experimental and control groups). Fourth, the GLM test was used to determine whether there was a significant difference between the learners' scores in pre- and post-test within the one group (control and experimental group). Next, an Independent Sample T-Test was used to compare the oral tests' scores between the control and experimental group. Finally, a paired sample t-test was run to assess which elements of speaking scores EFL learners improved the most.

\subsubsection{Analysis 2: Students' attitudes towards mobile video recording task-based approach for practicing speaking skills}

First, the internal consistency reliability was assessed by computing Cronbach's alpha. Second, a Descriptive Statistics Test was run to examine the overall learners' attitudes towards using mobile video recording as a tool in practicing speaking skill. (Mean of each item, Mean of each cluster, and Mean of the 35 items). Next, a One Sample T-Test was conducted to check whether the mean score of learners' perception of using mobile video recording as a tool in practicing speaking skill is statistically different from the test value of 4.0, a high level of agreement in the five-degree scale. In terms of the interview, all transcripts of the interviews were translated into English, read carefully, and coded using thematic analysis (Boyatzis, 1998). Then participants' responses were clustered into themes basing on their similarities and differences. Four key themes were formed: (1) EFL learners' attitudes towards the employment of using mobile video recording to practice speaking skills; (2) EFL learners' attitudes towards the benefits of using mobile video recording; (3) EFL learners' attitudes towards the challenges of using mobile video recording and (4) EFL learners' recommendation of using mobile video recording.

\section{Findings}

This section presents the findings of the study regard to students' speaking performance before and after the intervention and students' perception towards the using mobile video recording to practice speaking skills.

\subsection{Students' speaking performance before and after the intervention}

\subsubsection{Participants' speaking scores within the two groups before and after the study}

Table 4.1.1a:Mean difference of students' speaking scores within control group

\begin{tabular}{ccccccc}
\hline Group & Tests & N & Minimum & Maximum & Mean & Std. Deviation \\
\hline Control & Pre-test & 20 & 2.50 & 5.50 & 3.95 & 1.03 \\
\hline & Post-test & 20 & 3.25 & 6.38 & 4.78 & 1.14
\end{tabular}

The results showed the difference of means in the pre-test and post-test ( p pre=3.95; SD=1.03, p post=6.38; $S D=1.14),(d f=1, p=0.00)$. It can be concluded that after eight weeks of intervention, students' speaking skills of control group was improved. 
DOI: $\underline{10.51386 / 25815946 / i j s m s-v 4 i 4 p 111}$

Volume: 4 Issue: 4

July to August 2021

https://www.ijsmsjournal.org

Afterward, the General Linear Model test was carried out to identify the difference of mean score of experimental group's pretest and posttest $(p=0.00)$ led to a conclusion that it was fully confident that the speaking performance of the experimental group was different at pretest and posttest. Later, the mean scores of the pre-test and post-test were clarified by Descriptive Statistic Test.

Table 4.1.1b: Mean difference of students' speaking scores within experimental group

\begin{tabular}{ccccccc}
\hline Group & Tests & N & Minimum & Maximum & Mean & Std. Deviation \\
\hline Experimental & Pre-test & 20 & 2.25 & 5.38 & 3.81 & 0.88 \\
& & & & & & \\
\hline & Post-test & 20 & 4.38 & 6.63 & 5.46 & 0.67
\end{tabular}

The mean score of the pretest was different from posttest's mean score. (Mpre $=3.81 ; S D=0.88, M$ post $=5.46$; $S D=0.67)(D f=1, p=0.00)$. Theresult indicates that the mean of the post-test was higher than that of the pre-test. After the study, the speaking performance of experimental group was significantly increased.

\subsubsection{Participants' speaking scores between the two groups before and after the intervention}

To evaluate students' speaking scores between the two groups before and after the intervention, the Descriptive Statistic Test, the Independent Sample T Test and the General Linear Model test were carried out. First, the results of the Descriptive Statistic Test are presented in table 4.1.2 below.

Table 4.1.2: Students' speaking scores between the two groups

\begin{tabular}{llccccc}
\hline \multicolumn{1}{c}{ Group } & $\begin{array}{c}\text { Minim } \\
\text { Um }\end{array}$ & $\begin{array}{c}\text { Maxim } \\
\text { Um }\end{array}$ & Mean & $\begin{array}{c}\text { Std. } \\
\text { Deviation }\end{array}$ & N \\
\hline \multirow{2}{*}{ Pretest } & Experimental group & 2.25 & 5.38 & 3.81 & 0.88 & 20 \\
\cline { 2 - 7 } & Control group & 2.50 & 5.50 & 3.95 & 1.03 & 20 \\
\hline \multirow{2}{*}{ Posttest } & Experimental group & 4.38 & 6.63 & 5.46 & 0.67 & 20 \\
& Control group & 3.25 & 6.38 & 4.78 & 1.14 & 20 \\
\hline
\end{tabular}

4.1.2.1. Students' speaking performance between the two groups before the intervention

In the pre-test, the mean score of the control group $(M=3.95)$ was a little bit higher than the mean score of the experimental group $(M=3.81)$. To check whether there was a significant difference in the students' vocabulary retention in the pre-test between the control group and the experimental group, an Independent Sample T Test was run. The result showed that the difference in the students' vocabulary retention in the pre-test between the two groups was not significant $(t=0.495, d f=38, p=.621>$ alpha $(5 \%))$. This meansthat students' speaking performance in the pre-test of two groups was the same. The two groups were distributed homogenously before the intervention.

Table 4.1.2.1: Comparing pretest results of the two groups

\begin{tabular}{llllll}
\hline Variable & M & SD & $\boldsymbol{T}$ & $\boldsymbol{d f}$ & $\boldsymbol{p}$ \\
\hline Speaking Pretest & & & & & \\
Experimental Group & 3.81 & 0.88 & 0.49 & 38 & 0.621 \\
Control Group & 3.95 & 1.03 & & \\
Independent Samples T-Test & & & & \\
\hline
\end{tabular}


DOI: $\underline{10.51386 / 25815946 / \mathrm{ijsms}-\mathrm{v} 4 \mathrm{i} 4 \mathrm{p} 111}$

Volume: 4 Issue: 4

July to August 2021

https://www.ijsmsjournal.org

\subsubsection{Students' speaking scores between the two groups after the intervention}

Table 4.1.2.2 also revealed that the students' speaking performance between the two groups was different after the intervention. After eight weeks of the intervention, the means of the post-test of both groups were highly improved (Mpost=4.78 for the control group, experimental Mpost=5.46 for the experimental group). The Independent Samples t-test was run to compare the results. From the table above, we could draw the sig. $=.030$ $<$ alpha (5\%). Therefore, we could conclude that the result of the Independent Samples t-test shows that the speaking skills of the two groups were a statistically significant difference.

Table 4.1.2.2: Comparing posttest results of the two groups

\begin{tabular}{llllll}
\hline Variable & M & SD & $\boldsymbol{T}$ & $\boldsymbol{d} f$ & $\boldsymbol{P}$ \\
\hline Speaking Pretest & & & & \\
Experimental Group & 5.46 & 0.67 & -2.27 & 38 & 0.030 \\
Control Group & 4.78 & 1.14 & & \\
Independent Samples T-Test & & & & \\
\hline
\end{tabular}

\subsubsection{Students speaking elements' scores of the experimental group after the intervention}

Table 4.1.3 Comparing students speaking elements' scores of the experimental group

\begin{tabular}{lllll}
\hline Variable & Pretest $\mathbf{M}$ & $\begin{array}{l}\text { Posttest } \\
\mathbf{M}\end{array}$ & $\begin{array}{l}\text { Mean } \\
\text { Diff }\end{array}$ & Sig. (2-tailed) \\
\hline Fluency & 3.575 & 5.575 & 1.925 & 0.000 \\
Vocabulary & 3.575 & 5.6 & 1.875 & 0.000 \\
Pronunciation & 3.75 & 5.425 & 1.100 & 0.000 \\
Grammar & 4.125 & 5.575 & 1.675 & 0.000
\end{tabular}

Paired Samples T-Test

Firstly, the results presented in the table above showed that there was a significant difference between the students' mean scores of Fluency before using mobile self-recording video clips $(\mathrm{M}=3.575)$ and after the treatment $(\mathrm{M}=5.575)$ condition: $\mathrm{df}=19$, sig $=0.000$. This means that there are statistically significant differences because $\mathrm{P}$ value less than 0.05 level between students' mean scores in the paired sample in the post oral test due to fluency skill. The result emphasized that using self-recording video in practicing speaking skills enhances EFL learners' fluency.

Secondly, the results which shown in the table above revealed that there was a significant difference between the students' mean scores of vocabulary before using mobile learning $(\mathrm{M}=3.575)$ and after using mobile learning $(M=5.6)$ conditions: $\mathrm{df}=19, \mathrm{P}=0.000$. This result explored that there are differences, because $\mathrm{P}$ value (sig) $=0.000$ less than 0.05 level between students' mean scores in the paired sample in the post oral test due to vocabulary skill. Hence, the result confirmed that using mobile learning applications can effectively support activities of vocabulary learning.

Thirdly, the results given in table 5.1 indicated that there was a significant difference between the students' mean scores of pronunciations before using mobile learning $(M=4.125)$ and after using mobile 
DOI: $\underline{10.51386 / 25815946 / \mathrm{ijsms}-\mathrm{v} 4 \mathrm{i} 4 \mathrm{p} 111}$

learning $(\mathrm{M}=5.575)$ conditions: $\mathrm{df}=19, \mathrm{P}=0.000$. This means that there are differences, because $\mathrm{P}$ value $(\mathrm{sig})=$ 0.000 less than 0.05 level between students' mean scores in the paired sample in the post oral test due to pronunciation skill. This result confirmed that using mobile video recording could help learners improve their pronunciation of English in particular.

Fourthly, due to the results in table 5.1, there was a significant difference between the students' mean scores of accuracy of grammar before using mobile learning $(\mathrm{M}=3.75)$ after using mobile learning $(\mathrm{M}=5.425)$ conditions: $\mathrm{df}=19, \mathrm{P}=0.000$. This means that there are differences, because $\mathrm{P}$ value $(\mathrm{sig})=0.001$ less than 0.05 level between students' mean scores in the paired sample in the post oral test due to accuracy of grammar. The result confirmed that using mobile learning applications and activities can effectively improve the accuracy of using grammatical range in context which implies the use of a great variety of language structures or grammar rules to better comprehend English in context.

In conclusion, the improvement of speaking skills was observed between the pretest and the posttest of control group and experimental group after eight weeks. The result showed that there was significant difference about the speaking scores between the two groups after the intervention. Besides, there were significant differences about the speaking element's scores in the experimental group. This fact leads to a consideration that students who use Mobile self-recording video clips were able to enhance their speaking skills.

\subsection{Students' attitudes towards mobile video recording task-based approach}

\subsubsection{EFL learners' time of preparing and making a video in practicing speaking skills.}

A Frequency Statistic Test was run to measure students' time of preparing and making a video in practicing speaking skills.

Table 4.2.1: Time students practicing and making a video clip to practice speaking skills

\begin{tabular}{|c|c|c|c|c|c|}
\hline & & Frequency & Percent & Valid Percent & $\begin{array}{l}\text { Cumulative } \\
\text { Percent }\end{array}$ \\
\hline \multirow[t]{4}{*}{ Valid } & $\begin{array}{l}\text { Under } 30 \text { minutes per } \\
\text { clip }\end{array}$ & 4 & 20 & 20 & 20 \\
\hline & $\begin{array}{l}\text { Between } 30 \text { and } 60 \\
\text { minutes per week }\end{array}$ & 10 & 50 & 50 & 70 \\
\hline & $\begin{array}{l}\text { Over } 60 \text { minutes Per } \\
\text { week }\end{array}$ & 6 & 30 & 30 & 100.0 \\
\hline & Total & 20 & 100.0 & 100.0 & \\
\hline
\end{tabular}

From the table, 4 participants just need under 30 minutes to prepare and make a video clip (20\%), while 6 participants need over 60 minutes (30\%). Many of the participants practice speaking skills with mobile video recording between 30 and 60 minutes (10 participants, 50\%). It can be assumed that the participants worked with mobile video recording in practicing speaking skills at an average time. 
DOI: $\underline{10.51386 / 25815946 / i j s m s-v 4 i 4 p 111}$

Volume: 4 Issue: 4

July to August 2021

https://www.ijsmsjournal.org

\subsubsection{EFL learners' attitudes towards the employment of using mobile video recording to practice speaking skills}

Section 2 of the questionnaires of 14 items presents EFL learners' attitudes towards the employment of using mobile video recording to practice speaking skills, as shown in Table 4.2.2

Table: 4.2.2 EFL learners' attitudes towards of the employment of using mobile video recording

\begin{tabular}{|l|l|c|c|c|c|c|c|}
\hline & \multicolumn{1}{|c|}{ SD \& D } & \multicolumn{2}{|c|}{ N } & \multicolumn{2}{|c|}{ SA \& A } \\
\cline { 2 - 7 } & Items & $\mathbf{F}$ & $\mathbf{P}$ & $\mathbf{F}$ & $\mathbf{P}$ & $\mathbf{F}$ & P \\
\hline 1 & I enjoy using MVR to record my speech. & 6 & 30 & 2 & 10 & 12 & 60 \\
\hline 2 & I often submit my video recording assignment on time. & 2 & 10 & 3 & 15 & 15 & 75 \\
\hline 3 & $\begin{array}{l}\text { I often follow my lecturer' instructions about the } \\
\text { templates of the speaking video. }\end{array}$ & 2 & 10 & 1 & 5 & 17 & 85 \\
\hline 4 & $\begin{array}{l}\text { Making a short video between 1 and 2 minutes is not } \\
\text { problematic to me. }\end{array}$ & 4 & 20 & 3 & 15 & 13 & 65 \\
\hline 5 & $\begin{array}{l}\text { It is convenient to submit videos to my teacher (via } \\
\text { Zalo). }\end{array}$ & 3 & 15 & 1 & 5 & 16 & 80 \\
\hline 6 & $\begin{array}{l}\text { I often watch my video clips many times before } \\
\text { submitting to my teacher. }\end{array}$ & 3 & 15 & 3 & 15 & 14 & 70 \\
\hline 7 & $\begin{array}{l}\text { Video clips are convenient for me to review and } \\
\text { practice. }\end{array}$ & 3 & 15 & 4 & 20 & 13 & 65 \\
\hline 8 & $\begin{array}{l}\text { Whenever I have time, I often watch my videos again to } \\
\text { recognize my mistake and try to improve myself. }\end{array}$ & 7 & 35 & 3 & 15 & 10 & 50 \\
\hline 9 & $\begin{array}{l}\text { I try not to make the same mistakes for the subsequent } \\
\text { videos. }\end{array}$ & 3 & 15 & 0 & 0 & 17 & 85 \\
\hline 10 & $\begin{array}{l}\text { I apply what my teacher advised in order to make better } \\
\text { speaking videos. }\end{array}$ & 2 & 10 & 1 & 5 & 17 & 85 \\
\hline 11 & I practice speaking many times before recording a video. & 3 & 15 & 3 & 15 & 14 & 70 \\
\hline 12 & $\begin{array}{l}\text { Making a speaking video is a valuable learning } \\
\text { experience. }\end{array}$ & 3 & 15 & 3 & 15 & 14 & 70 \\
\hline 13 & $\begin{array}{l}\text { Making a speaking video makes my learning more } \\
\text { enjoyable. }\end{array}$ & 5 & 25 & 2 & 10 & 13 & 65 \\
\hline 14 & \begin{tabular}{l} 
Making a speaking video motivates me to learn English. \\
\hline
\end{tabular} & 2 & 10 & 3 & 15 & 15 & 75 \\
\hline
\end{tabular}

Note: F=Frequency; $\mathbf{P}=$ Percentage; $\mathbf{S D} \& \mathbf{D}=$ Strongly disagree $\&$ disagree; $\mathbf{N}=$ Neutral; $\mathbf{S A} \& \mathbf{A}=$ Strongly agree $\&$ agree

Table 4.2.2 showed that most of the respondents carried out the treatment quite well with the highest extent (items 3, 9, 10 and 5; $n=17$ and $n=16)$. Most students $(85 \%)$ agreed that they follow the teacher's instructions about the templates of speaking video, they try not to make the same mistakes for the subsequent videos and they apply what teacher advised in order to make better speaking video. Moreover, $80 \%$ of the participants $(n=16)$ affirmed that it is convenient for them to submit the video via social media (Zalo). $75 \%$ of the participant $(n=15)$ agreed that they often submit the speaking video to the teacher on time and making a speaking video motivates them to learn English. Besides, $70 \%$ of the participant agreed that they often practice speaking and watch the video many times before recording and submitting to the teacher and making a speaking video makes their learning more enjoyable.

Table 4.2.2 also showed a medium percentage (65\%) of item 4, 7, 13 and 1 . In item 4, only 13 participants agreed that making a video between 1 and 2 minutes is not problematic to them. It is impossible to ensure that students do not have any challenges in speaking videos without a doubt. Such challenges were 
DOI: $\underline{10.51386 / 25815946 / i j s m s-v 4 i 4 p 111}$

Volume: 4 Issue: 4

July to August 2021

https://www.ijsmsjournal.org

discussed in the interview session. In terms of the interest, only 13 participants agreed that they enjoy doing mobile video recording to practice speaking video.

Item 8 received a lowest percentage $(8 \%)$, it is pretty sure that students do not agree that whenever they have free time, they watch video again to recognize the mistakes and try to improve by themselves. Despite following most of the lecturer's instructions and they time they spend for making speaking video, students still admit that watching their videos in their free time is a tough job to do.

\subsubsection{EFL learners' attitudes towards the effects of using mobile video recording to practice speaking skills}

Section Three of the questionnaire consists of thirteen items with regard to EFL learners' attitudes towards the effects of using mobile video recording to practice speaking skills.

The mean score of twelve items of learners' attitudes towards the benefits is shown in Table 4.2.3.a

Table 4.2.3a: The mean score of students' attitudes towards the effects of using mobile video recording

\begin{tabular}{lccccc}
\hline N & Minimum & Maximum & Mean & $\begin{array}{c}\text { Std. } \\
\text { Deviation }\end{array}$ \\
\hline Effect Mean & 13 & 1.38 & 4.23 & 3.61 & .736 \\
\hline
\end{tabular}

A Descriptive Statistic Test was run to check the overall mean score of students' attitudes towards the effects of using mobile video recording in practicing speaking skills. Regarding Oxford's (1990) scale, the overall mean score is at a high level $(M=3.61, S D=.736)$. It can be inferred that the students clearly perceived the effects of using mobile video recording to practice speaking skills.

Table: 4.2.3.c Mean score of twelve clusters of EFL learners' attitudes towards the effects of using mobile video recording to practice speaking skills.

\begin{tabular}{|l|l|l|l|l|l|}
\hline Item & N & Min & Max & Mean & SD \\
\hline Confidence & 20 & 1.00 & 5.00 & 3.70 & 0.97 \\
\hline Autonomy & 20 & 1.00 & 5.00 & 3.60 & 1.14 \\
\hline Chance to Practice English & 20 & 1.00 & 5.00 & 4.00 & 1.07 \\
\hline Fluency & 20 & 1.00 & 5.00 & 3.50 & 1.00 \\
\hline Grammar & 20 & 1.00 & 5.00 & 3.50 & 1.14 \\
\hline Pronunciation & 20 & 1.00 & 5.00 & 3.65 & 1.13 \\
\hline Vocabulary & 20 & 1.00 & 5.00 & 3.50 & 1.10 \\
\hline Feedback & 20 & 1.00 & 5.00 & 4.00 & 1.02 \\
\hline Self-reflection & 20 & 2.00 & 5.00 & 3.95 & 0.82 \\
\hline Topic Knowledge & 20 & 1.00 & 5.00 & 3.40 & 1.04 \\
\hline Presentation Skills & 20 & 1.00 & 5.00 & 3.30 & 1.34 \\
\hline Research Skills & 20 & 1.00 & 5.00 & 3.05 & 0.94 \\
\hline
\end{tabular}

As can be seen from Table 4.2.3.c, the mean score of twelve items of participants' agreement range from 3.05 to 4.0, indicating that students believed that using mobile video recording to practice affected on students' speaking performance. Of the twelve items, chances to practice English and Feedback got the highest mean 
DOI: $\underline{10.51386 / 25815946 / \mathrm{ijsms}-\mathrm{v} 4 \mathrm{i} 4 \mathrm{p} 111}$

Volume: 4 Issue: 4

July to August 2021

https://www.ijsmsjournal.org

score ( $M=4.0)$ followed by Self-reflection $(M=3.95)$, Confidence $(M=3.70)$, Pronunciation $(M=3.65)$, Autonomy (M=3.60). Next, the mean score of Fluency, Grammar and Vocabulary $(M=50)$ at the eighth place. The cluster Presentation Skill and Research Skill had the lowest mean score (M=3.30, and M=3.05)

A One-Sample T Test was conducted to check whether the mean score of each cluster is statistically different from the test value of 4.5 , a very high value of agreement.

Table 4.2.3.d Mean of each cluster compares to the test value

\begin{tabular}{|l|c|c|c|}
\hline & \multicolumn{2}{|l}{ Test Value $\mathbf{4 . 5}$} \\
\hline Cluster & \multicolumn{1}{|l|}{ t } & \multicolumn{1}{l|}{ Df } & Sig. (2-tailed) \\
\hline Confidence & -3.655 & 19 & 0.02 \\
\hline Autonomy & -3.523 & 19 & 0.02 \\
\hline Chance to Practice English & -2.078 & 19 & 0.52 \\
\hline Fluency & -4.472 & 19 & 0.00 \\
\hline Grammar & -3.899 & 19 & 0.01 \\
\hline Pronunciation & -3.344 & 19 & 0.03 \\
\hline Vocabulary & -4.472 & 19 & 0.00 \\
\hline Feedback & -2.179 & 19 & 0.42 \\
\hline Self-reflection & -2.979 & 19 & 0.08 \\
\hline Topic Knowledge & -3.500 & 19 & 0.02 \\
\hline Presentation Skills & -4.000 & 19 & 0.01 \\
\hline Research Skills & -6.866 & 19 & 0.00 \\
\hline
\end{tabular}

From the Table 4.2.3.d, the results showed that the difference between the participants' perception towards the benefits of using mobile video recording and the test value (4.5) was significant different $(\mathrm{t}=-3,655$; $\mathrm{p}=0.02<0.05 ; \mathrm{t}=-3,523 ; \mathrm{p}=0.02<0.05 ; \mathrm{t}=-4.472 ; \mathrm{p}=0.00<0.05 ; \mathrm{t}=-3.899, \mathrm{p}=0.01<0.05 ; \mathrm{t}=-3.344, \mathrm{p}=0.03<0.05$; $\mathrm{t}=-4.472, \mathrm{p}=0.00<0.05 ; \mathrm{t}=-3.500, \mathrm{p}=0.02<0.05 ; \mathrm{t}=-4.000, \mathrm{p}=0.01<0.05 ; \mathrm{t}=-6.866, \mathrm{p}=0.00<0.05)$. Therefore, leaner's' perception towards the benefits of using mobile video recording regarding confidence, autonomy, fluency, grammar, pronunciation, vocabulary, topic knowledge, presentation skills and research skills are at high level. Besides, students' perception towards the benefits of using mobile video recording in terms of chances to speak English, feedback and self-reflection is at very high level because the results showed that the difference between the participants' perception and the test value (4.5) was not different $(\mathrm{t}=-2.078 ; \mathrm{p}=0.52>0.05 ; \mathrm{t}=-2.179$; $\mathrm{p}=0.42>0.05 ; \mathrm{t}=-2.079, \mathrm{p}=0.08>0.05)$

\subsubsection{EFL learners' attitudes towards the challenges of using mobile video recording to practice speaking skills}

Section Four of the questionnaire consists of nine items with regard to EFL learners' attitudes towards the challenges of using mobile video recording to practice speaking skills. The mean score of nine items of learners' attitudes towards the challenges is shown in Table 4.2.4.a 
DOI: $\underline{10.51386 / 25815946 / i j s m s-v 4 i 4 p 111}$

Table 4.2.4a: The mean score of students' attitudes of the effects of using mobile video recording

\begin{tabular}{lccccc}
\hline & & Minimum & Maximum & Mean & Std. \\
& & & & & Deviation \\
& & & & & \\
\hline Challenge Mean & 8 & 1.63 & 2.63 & 2.00 & .259 \\
\hline
\end{tabular}

A Descriptive Statistic Test was carried out to examine the total mean score of students' attitudes towards the challenges of using mobile video recording. From the table 4.2.4.a, the total mean score is at a high level $(\mathrm{M}=2.00, \mathrm{SD}=0.25)$. The results support that students did not perceive the challenges of using mobile video recording to practice speaking skills.

Table: 4.2.4.b Mean score of nine items of EFL learners' attitudes towards the challenges of using mobile video recording to practice speaking skills.

\begin{tabular}{|c|c|c|c|c|c|}
\hline Item & $\mathbf{N}$ & Min & Max & Mean & SD \\
\hline I feel uncomfortable speaking in front of the camera. & 20 & 1.00 & 3.00 & 2.20 & 0.523 \\
\hline $\begin{array}{l}\text { I often have technical problems during recording the } \\
\text { clip. }\end{array}$ & 20 & 1.00 & 3.00 & 1.95 & 0.825 \\
\hline $\begin{array}{l}\text { Making speaking videos is not useful to develop } \\
\text { speaking skills. }\end{array}$ & 20 & 1.00 & 3.00 & 1.65 & 0.587 \\
\hline Making speaking videos is a time-consuming activity. & 20 & 1.00 & 3.00 & 2.00 & 0.648 \\
\hline $\begin{array}{l}\text { I often have difficulty with vocabulary when recording } \\
\text { the video clip }\end{array}$ & 20 & 2.00 & 3.00 & 2.25 & 0.444 \\
\hline $\begin{array}{l}\text { I often have difficulty with grammar when recording } \\
\text { the video clip. }\end{array}$ & 20 & 1.00 & 3.00 & 2.10 & 0.640 \\
\hline $\begin{array}{l}\text { I often have difficulty with fluency when recording the } \\
\text { video clip }\end{array}$ & 20 & 1.00 & 3.00 & 1.95 & 0.604 \\
\hline $\begin{array}{l}\text { I often have difficulty with pronunciation when } \\
\text { recording the video clip. }\end{array}$ & 20 & 1.00 & 3.00 & 1.90 & 0.640 \\
\hline
\end{tabular}

As can be seen from Table 4.2.3.c, the mean score of eight items of participants' agreement range from 1.65 to 2.20 , indicating that students disagreed that using mobile video recording to practice has challenges for them to practice speaking skills.

4.3 EFL students' understanding of using mobile video recording in practicing speaking skills in the experimental group in term of benefit, drawbacks, challenges and recommendation

Insight into students' attitudes towards the benefits of using mobile video recording to practice speaking skills

The face-to-face semi-structured interviews were audio-recorded and transcribed. In the first interview question, the learners were asked about the probable effects of mobile self-recording video to practice speaking skill. In response to this question, it was comprehended that the self-recording video had the positive impact on the 
DOI: $\underline{10.51386 / 25815946 / \mathrm{ijsms}-\mathrm{v} 4 \mathrm{i} 4 \mathrm{p} 111}$

Volume: 4 Issue: 4

July to August 2021

https://www.ijsmsjournal.org

learners to produce the utterances in the target language. Besides, the learners indicate that the videos that were recorded assisted the learners to gain self-confidence. The responses of the learners were demonstrated below.

- "I believe that I can practice and improve my speaking skills with this activity. If I speak in front of a lot of people or communicate with friends or give presentations in class, I feel more confident." (Participant 1, line 14).

- “After 2 months, I believe that my speaking skill has improved.” (Participant 2, line 14)

- "I think my speaking skill improves because if I speak normally, I cannot listen again, but if I record video clips, I can listen to these clips again and be able to realize my mistakes." (Participant 3, line 14).

- "I find this activity favorable. It provides excitement to me and I also get curious about each topic for the clip." (Participant 4)

- 'It is exciting, really. Participants' recording their own videos is really exciting, it also helps me to become confident." (Participant 5)

- $\quad$ "I believe that the videos will provide self-confidence to ourselves. I think that we speak more comfortably in the videos." (Participant 6)

In terms of vocabulary, all learners agreed that they could learn a wide range of vocabulary because they have to remember the new words and practice a lot to make video clips before submitting to the teacher. According to student 2's and student 4's opinion

- "I can learn a lot of vocabulary because I have to practice a lot to remember the vocabulary." (Participant 2, line 16)

- "I can learn a lot of vocabulary because I have to learn new words to make video clips." (Participant 4, line 16)

- "I know how to use new words and learn a lot of difficult words." (Participant 5)

In terms of grammar, four learners stated that they could learn a wide range of grammar points, try not to make mistakes when it comes to tenses and use grammar better for the next clip,

- "Before making a video clip, I have to find suitable structures, so I can learn and know how to use these grammar points." (Participant 1)

- "I can use complex structures instead of simple ones." (Participant 3).

while student 2 said that he still makes mistakes when he speaks.

- "Although I have practiced many times, I still forgot to use the right verb, especially the simple past tense." (Participant 2)

- "I believe my grammar has improved because I have time to prepare the scripts before I speak." (Participant 5)

In terms of pronunciation, all learners feel they can improve a little bit, but they need the support from teacher.

- "I think I also improve my pronunciation, especially keeping the final sounds which I used to forget before." (Participant 1) 
DOI: $\underline{10.51386 / 25815946 / i j s m s-v 4 i 4 p 111}$

- "I used to make a lot of mistakes about pronunciation, but when I watch my video clips many times, I can realize my mistakes and try to avoid them next time." (Participant 2).

- "At home, I have enough time to look up the phonetic of each word and try to pronounce before making a video clip, so my pronunciation also improves. ” (Participant 5)

In terms of fluency, learners also think that they can speak more fluently than before because of the practicing time. They are confident to speak fluently in the video clips instead of face-to-face conversation.

- "I believe I can speak more fluently than before." (Participant 1, line 22)

- " After making a lot of video clips, I feel more confident and speak more fluently." (Participant 2 , line 22)

- "Especially the fluency, when I have the scripts with the suitable time to practice, I can speak fluently in the clips rather than speaking in front of the teacher." (Participant 5)

Insight into students' attitudes towards the drawbacks of using mobile video recording to practice speaking skills

To the degree of the following question, the viewpoints of the participants were asked if they believed that there are any drawbacks or insulting points related to the self-recording videos. Although it was expected from the learners to share their negative experiences they confronted during this activity, five of six participants disagreed that the video recordings have any drawbacks or insulting points on the learners. In default of this, the learners emphasized that they learned from the mistakes by virtue of their own recorded videos. The answers of the learners to the question were indicated below.

- "I do not think that it is insulting. Thanks to this activity, I can learn from my mistakes." (Participant 1)

- $\quad$ "No, it is beneficial, I suppose, because it provides people to gain the confidence. I mean there is a confidence about speaking by yourself during two minutes" (Participant 2)

- "There are occasionally some problems related to the pronunciation of my speaking skill. However, with this activity, I can fix the mistakes." (Participant 3)

- "I cannot find any drawbacks from this activity. I don't think this activity is time-consuming, because when you want to improve something, you have to practice a lot." (Participant 6)

Insight into students' attitudes towards the challenges of using mobile video recording to practice speaking skills

Five of six participants contended that preparing stage before making a video clip is quite challenging for them because they have to reconstruct the old lessons and teachers' explanation at home to be their own knowledge in order to perform well in the video clips. Moreover, sometimes they do not know how to speak logically, so it makes them confused.

- "Whenever I make a video clip, it takes me a lot of time to prepare for the clip, especially the content of the clip."

- "I have no idea whether I use the correct vocabulary and grammar or not, so it makes me confused."

- "My difficulty is that when I make a video clip, I cannot order the sentence logically or express my ideas smoothly. Therefore, I sometimes cannot speak logically." 
DOI: $\underline{10.51386 / 25815946 / i j s m s-v 4 i 4 p 111}$

- "I find it hard to prepare for the script. In fact, I cannot complete the clip at the first time, so I have to record video many times to make it perfect and send to teacher. I think it is the only challenge for me."

Insight into students' attitudes towards the recommendation of using mobile video recording to practice speaking skills

Considering the replies of the last interview question, each participant indicated an interesting way to assist the researcher use this activity better in the future. Three of them stated that the teacher should provide them with templates for speaking videos to follow while two participants said that topic is the most important thing for this exercise because if learners are into the topics, they are willing to practice without being blamed by the teacher. The last participant believed that teacher should ask students to submit the video clip once a week instead of twice a week in the experiment. The answers of the last question are indicated below.

- "I think teacher should provide the vocabulary and structures to help me make the clips better." (Participant 1, line 32)

- $\quad$ "In order to make better clips, teacher should provide suitable vocabulary and structures and the topics should be specific, not too general." (Participant 2, line 32)

- "Well, I think I need the help from teacher, she should give us more vocabulary and grammar points or something like that, so I can make better clips.” (Participant 4)

- $\quad$ "In my opinion, the topics should be related to learners' interest, so they can be motivated to make video clips." (Participant 3)

- $\quad$ "For me, I only feel motivated to speak in the clip when it comes to my favorite topic, so teacher should consider the topic." (Participant 6)

- "I think instead of requiring two video clips per week, teacher should ask the student do only one in order to make the learners not feel bored when they make video clips." (Participant 5)

To sum up, the mobile self-recording videos have a favorable effect on the learners' speaking skills in the target language. Besides, recording self-videos provide the opportunities to the learners such as increasing the number of vocabulary, gaining self-confidence while speaking in the target language, repairing the pronunciation mistakes, improving grammar points and being able to practice the language effectively. In the challenging question, the learners indicate that it takes them a lot of time to prepare and complete a video.

\section{Discussion}

In this section, the main findings of the current study were discussed and concluded relating to the research questions.

\section{The Effect of mobile video recording on students' speaking performance}

The results of General Linear Model demonstrated the comparison between the pretest and posttest mean scores of the Experimental Group in terms of fluency, grammar, vocabulary, pronunciation. It also reveals Sig. for the comparison of the average scores of pretest and posttest. This indicates that the mean difference was -1.647 . Moreover, Sig. for the comparison of the average scores of pretest and posttest was $p=0.00<\alpha(5 \%)$. Thus, the difference in pretest-posttest scores was statistically different.

For the Vocabulary criterion, the pretest mean score was $3.56(\mathrm{M}=3.56)$, the posttest mean score was $5.6(\mathrm{M}=5.6)$, this indicates the mean difference was -1.875 and the Sig for the comparison of the average scores of pretest and posttest was as $\mathrm{p}=0.00<\alpha(5 \%)$. Thus, the difference in the pretest-posttest scores was a statistically significant difference, and the researcher could tell from the means that posttest scores were higher. 
DOI: $\underline{10.51386 / 25815946 / \mathrm{ijsms}-\mathrm{v} 4 \mathrm{i} 4 \mathrm{p} 111}$

Volume: 4 Issue: 4

July to August 2021

https://www.ijsmsjournal.org

This result was similar to the results obtained in Sun (2012), Huang and Hung (2010), Castañeda and Rodríguez-González (2011), Huang (2008), Nazlinur (2016), Kırkgöz (2011) and Mennim (2003). According to these authors, the learners sometimes got stuck in their speeches due to lack of some topic-related vocabulary items at their disposal, and they had to shoot the videos one more time after they looked up the unknown words. Furthermore, they could easily recall the words that they used during their video recordings after two or three weeks, which indicates that digital video recordings created a learning opportunity for them and helped them to access new vocabulary items easily. Video recordings also helped the learners to expand their theme-related vocabulary. Besides, this treatment succeeded to improve students' vocabulary.

For the Fluency criterion, the pretest mean score was $3.575(\mathrm{M}=3.575)$, the posttest mean score was $5.575(\mathrm{M}=5.575)$, this indicates the mean difference was -1.925 and the Sig. for the comparison of the average scores of pretest and posttest was as $\mathrm{p}=.00<\alpha(5 \%)$. Thus, the difference in pretest-posttest scores was a statistically significant difference, and the researcher could tell from the means that posttest scores were higher. This result follows Skehan (1996), Aldy and Rahmila (2013), Castañeda and Rodríguez-González (2011), Nazlinur's (2016) and Sun (2009) that to achieve the first goal, fluency, learners aim to use the target language in real-life situations at an adequate degree of speech rate without disturbing pauses. The result is, through this procedure most of the students were able to improve their reading fluency, as evidenced by their correct use of chunking, phrasing, intonation, and word stress. The learners from those reports said that they perceived an improvement in their speaking skills, in particular in fluency.

For the Grammar criterion, the pretest mean score was $3.75(\mathrm{M}=3.75)$, the posttest mean score was $5.425(\mathrm{M}=5.425)$, this indicates the mean difference was -1.1 and the Sig. for the comparison of the average scores of pretest and posttest was as $\mathrm{p}=.00<\alpha(5 \%)$. Thus, the difference in pretest-posttest scores was statistically significant. This result was consistent with results from Cooke (2013), Huang (2008), Lynch (2007), Stillwell et al. (2009) and Huang (2008) suggested that having student listen to non-native speaker authentic output is one way to enhance the student ability to focus on form. Lynch (2007) noted that the class in which students initiated self-transcribing and self-reflection outperformed inaccuracy. According to Pham and Nguyen (2014), training students on how to learn grammar with CLT could improve their grammatical knowledge and performance. Therefore, students could have simply memorized the revised dialogues and presentations. Yet, the students could use the grammatical knowledge they learn and they could use them correctly.

For the Pronunciation criterion, the pretest mean score was $4.125(\mathrm{M}=4.125)$, the posttest mean score was $5.575(\mathrm{M}=5.575)$, this indicates the mean difference is -1.675 and the Sig. for the comparison of the average scores of pretest and posttest as $p=.00<\alpha(5 \%)$. Thus, the difference in pretest-posttest scores is statistically very significant. Research results specific to pronunciation using voice recording have been revealed by Achiko (2014), Lord (2008), Ducate and Lomicka (2009). The results suggested that students' phonetic articulation improved after the project. Moreover, students' attitudes towards pronunciation also improved. Students can receive constructive written feedback and comments after they upload their recordings. In Brown's (2012) study, students were aware of their difficulty pronouncing specific segments of English sounds. As the project progressed, students' attention shifted from segmental (e.g., vowels and consonants) to suprasegmentals (e.g., intonation, linking, and sentential stress). The recording project was viewed as a success in enhancing the students' intelligibility.

The Independent Samples t-test was run to compare the posttest mean scores between two groups with the sig. $=.030<$ alpha $(5 \%)$. Therefore, we could conclude that the result of the Independent Samples t-test shows that the speaking skills of the two groups were a statistically significant difference. This means that recording video clips has influenced substantially on students' speaking skills. Explicitly, students' speaking means score in the experimental class has changed approximately 2 points from 2.25 to 4.38 . Besides, all the four criteria of the speaking performance have improved. Students' fluency has improved the most followed by vocabulary and Pronunciation. Students' Grammar skills have also improved but with little change. On the 
DOI: $\underline{10.51386 / 25815946 / \mathrm{ijsms}-\mathrm{v} 4 \mathrm{i} 4 \mathrm{p} 111}$

Volume: 4 Issue: 4

July to August 2021

https://www.ijsmsjournal.org

contrary, without the use of mobile video recording, students' speaking performance in the control group did not have a significant difference despite little change. Explicitly, students' speaking means the score has changed from 3.95 to 4.78. The results of this study confirmed Pham and Usaha's (2016) that in case the teacher knew how to make use of the effective technological tool in the classroom to train the students, the students would gain many benefits from it for their language development.

The main important question is what factors contributed the most to these positive effects. It is impossible to point out a single component, but rather a combination of interacting factors. First of all, the present method is similar to many of the previous task-based approaches in that it is useful for moving focus of the learning process from the teacher to the students. Secondly, since the tasks from their real-life situations, students get to improve their communication skills, confidence and motivation. Thirdly, a use of mobile video recording task-based approach gives students more opportunities to practice speaking English, so they acquire a deeper understanding of the language. Finally, making video clip assists students to be exposed to a whole range of lexical phrases, collocations and patterns as well as language forms. Meanwhile, all of the four speaking elements, EFL learners improved which vocabulary ranked the first, grammar and fluency ranked the second and the last position was pronunciation. In terms of vocabulary, students should practice using them more frequently in order to retain the words and remember longer. Thanks to mobile video task-based approach, students have many opportunities to use the new vocabulary during the course in different topic. These tasks help them retain vocabulary in their long term memories and use them while speaking. Therefore, through this approach, students would improve their vocabulary. Regarding to the fluency, as stated by Crawford (2002), sometimes the problems is the teachers or lectures simply not know what learners are interested in talking about, so students often find a dead way of talking something. Through mobile video recording task-based approach, students are accustomed to speak spontaneously and naturally since it deals with their interest such as favorite movies and sports or their own experiences like a pet that you had, so it is ideal for them to speak fluently with some familiar vocabulary. Besides, the results of grammar scores demonstrated that mobile video recording task-based approach could help students learn grammar more effectively. Lynch (2007), they noted that the class in which students carefully prepared the transcript and reflected their own performance by themselves could avoid making grammar mistakes. Therefore, with this activity, it promoted students' self-learning to learn and use grammar more correctly. The speaking element students improved the least is pronunciation, it is explained that because the English language has different sounds compared to Vietnamese, students find it hard to pronounce. Moreover, with the 2-month course, it is short time for students to improve such difficulties. However, they could keep the final sounds, use correct intonation with important words in a sentence. Therefore, this treatment could help learners their pronunciation as well.

\section{Students' attitudes towards using mobile video recording to practice speaking skills}

The findings revealed that students had high positive attitude toward using mobile video recording to practice speaking skills. Students indicated that with this activity, they have more opportunities to practice speaking means that having more time to practice speaking at home or outside the classroom. This result repeats the result of Solanki and Phil (2012), Fredenberg (2008), Kim (2014), Hsu et al. (2008), Henry and Cheryl (2012), Skiba (2007), Gehringer and Miller (2009), Jeremy (2015), Skiba (2007), Castañeda and Rodríguez-González (2011) Pop, Tomuletiu and David (2011), Swain and Lapkin (1995), Danny Huang and Alan Hung's (2010), and Nazlinur (2016). Moreover, fluency is the first of five scoring criteria in the speaking test, which received highly positive answers from students $(\mathrm{M}=1.63, \mathrm{SD}=.955)$. This result follows Skehan (1996), Aldy and Rahmila (2013), Castañeda and Rodríguez-González (2011), Nazlinur's (2016) and Sun (2009). Affirmatively, as regards the learners' perceptions on the effectiveness of digital video recording on their oral communication skills, the findings revealed that, interestingly, the learners have a positive attitude towards an improvement in their use of vocabulary $(\mathrm{M}=1.95, \mathrm{SD}=.639)$ which is consistent with the results obtained in Sun (2012), Danny Huang and Alan Hung (2010), Castañeda and Rodríguez-González (2011), Huang (2008), Nazlinur (2016), Kirkgöz (2011) and Mennim (2003) In terms of grammatical accuracy in oral output $(\mathrm{M}=1.87, \mathrm{SD}=.563)$, learner generally performed better after self-reflection (Cooke, 2013; Huang, 2008; Lynch, 2007; Stillwell et al., 2009). Huang 
DOI: $\underline{10.51386 / 25815946 / \mathrm{ijsms}-\mathrm{v} 4 \mathrm{i} 4 \mathrm{p} 111}$

Volume: 4 Issue: 4

July to August 2021

https://www.ijsmsjournal.org

(2008) suggested that having students listen to non-native speakers' authentic output is one way to enhance the students' ability to focus on form. Lynch (2007) noted that the class in which students initiated self-transcribing and self-reflection outperformed inaccuracy. Therefore, students could have simply memorized the revised dialogues and presentations. Yet, the students can use the grammatical knowledge they learn and they can use them correctly $(\mathrm{M}=1.85, \mathrm{SD}=.580)$. Research results specific to pronunciation using voice recording have been revealed by Achiko (2014), Lord (2008), Ducate and Lomicka (2009). The results suggested that students' phonetic articulation improved after the project. Moreover, students' attitudes towards pronunciation also improved. Students can receive constructive written feedback and comments after they upload their recordings. Students said that they gained useful feedback on their speaking mistakes through peer video recording $(\mathrm{M}=$ $1.90, \mathrm{SD}=.632$ ). In recording activities, feedback from teachers and peers seems to have a positive influence on the speaking performance of learners. Likewise, In Pop, Tomuletiu and David (2011), Castañeda and Rodríguez-González (2011), Cheng and Chau (2009), and Nazlinur's (2016), students' opinions and reactions were very positive, and they were actively engaged because it allows the rehearsal and editing of audio posts, and can also help save face and build confidence. Expectations of receiving feedback from their peers and teachers motivated the learners as well. Students gain feedback from teachers, friends and themselves (selfevaluation/self-reflection). The digital video recordings helped them to realize the common use of pause fillers and hesitation markers in their own speeches and how those disfluency markers in their speeches irritated them as listeners. More specifically, in Nazlinur's (2016) study, furthermore, students pointed out that sharing their videos with their friends gave them an opportunity to be involved in a real task that required the use of English. Thus, they had a chance to watch others' performances and learn from one another. The present study also revealed some challenges that participants might encounter while practicing speaking with mobile video recording. The most challenging problem is time; in fact, students said that they did not have enough time to make a video clip because of heavy workload from other subjects at school. This problem also stated by Fernandez (2010). He revealed that recording and watching videos takes time and it can seem not so interesting for some students. In the responses of participants of the present study, these barriers were also indicated. In addition, one of the most challenging is what students speak in the clip. The participants admitted that they usually got trouble with the vocabulary, the grammar and the ideas when they practice in the clips. It is worth noticing that teachers who are interested in using mobile video recording for their classroom should prepare for the possible drawbacks.

\section{Conclusions}

Thanks to the results of the present study, the researcher is able to prove her hypotheses and she will definitely know how to enhance the teaching and learning speaking in her own classes. Furthermore, with the desire of sharing and inspiring, several valuable suggestions were made to the teachers, the students as well as the teaching and learning speaking in Vietnam as follow:

-Firstly, as evidenced in this study, using video recording task-based approach can effectively help students improve their speaking ability not only for the tests but also for their real life's needs and their future. Moreover, students express their enjoyment and their positive perceptions towards the method. Therefore, the researcher suggests teacher should consider integrating video-recorded speaking tasks into their speaking class as a homework assignment or a speaking portfolio in order to help students have more opportunities to practice speaking at home.

-Secondly, although students showed respectable perception towards the methods from the questionnaires and semi-structured interview, there remaining some issues needed to consider.

- $\quad$ For technology ownership and usage: albeit possessing latest technology nowadays as smartphones with available internet connection at their accommodation, students have not taken advantages of it, especially for educational purposes. Therefore, as English teachers, we should help students do such a thing. Taking 
DOI: $\underline{10.51386 / 25815946 / \mathrm{ijsms}-\mathrm{v} 4 \mathrm{i} 4 \mathrm{p} 111}$

Volume: 4 Issue: 4

July to August 2021

https://www.ijsmsjournal.org

advantages of available technology and maximize its functions in order to help students' learning and minimize students' wasting time.

- $\quad$ For students' procedure of recording the videos: students said that they did not watch their videos again after each section even though they were told to do so. This can be clarified by the laziness and the apathy of students. Therefore, if it is possible, do it in class. Teachers cannot control how many time students watch their videos again at home but they can do it in class. The laziness of watching their videos several times can bring about the repetition of mistakes for the subsequent videos. Therefore, if teachers can control the first issue, then there is no worry for the second one.

-Thirdly, the curriculum developers from schools and universities in Vietnam should consider developing a specific task and putting it into the course. Video-recorded speaking task in speaking class should be obligatory rather than optional so that it would become a habit, then students will no longer feel extraordinary about video making.

Although the study has satisfactory science, there exist limitations in the present study. The first and foremost weakness of this study is the fact that the participants in the experimental group are not enough, so the results could not represent for all of students. Moreover, the samples in this study are non-English majored students, which is also a limitation of this study. The next limitation of the study is about the number of video recorded in this course. In a course of twenty-four meetings, only eight videos are relatively little with the aim to improve students' speaking. The last limitation is that the requirement of making video clip is only individual task, so it could not improve learners' interactive communication.

From the limitation discussed above, the researcher has a desire for proving respected recommendation for future studies. It is first suggested to employ a quasi-experimental design, in which the participants are more than twenty. The researcher believes that it is more valid for the results to be representative and generalized to the entire population. In addition, participants in this study are non-English majored students. Therefore, the researcher, who is and English teacher, wished that research could be carried out on the other two types of English classes so that the results can be drawn for the whole school English students. Furthermore, what has been done in this study can only be considered as the first step for further exploration of some other issues related to recording students' speech in speaking classes. If possible, future studies should cover more videos. The last suggestion is that instead of giving students only the individual tasks, teacher could ask learners to do the pair work or group work in order to helps students improve interactive communication or critical thinking by making debate videos or conversation.

\section{About the Authors}

TrangThiThienTran is a teacher of English at a foreign language center in Can Tho, Vietnam. She completed a bachelor's degree of English Teacher Education in 2018. She is currently an MA student at Can Tho University. Her research interests include speaking skills and strategies, and teaching methodology. She is also keen on improving the learning experience for EFL students and applying innovative approaches for both young and adult learners.

Hong Thi Phuong Nguyenhas been an English lecturer at Can Tho University since 1995. She graduated English Teacher Education at Can Tho University in 1995. In 2006, she got her master degree at Masschussetts, Boston, USA under the Fubright scholarship program granted by the US Government. The master's thesis is American Multiculturalism: Contact and Conflict between Ethnic Groups (A Curriculum Project). In 2013, she received her doctoral degree from the PhD program in Applied Linguistics and TEFL at the University of Groningen, Netherlands, under a TRIG scholarship granted by the Vietnamese Government. Her doctoral thesis is A Dynamic Usage-based Approach to Second Language Teaching. Her research focuses on foreign language 
DOI: $\underline{10.51386 / 25815946 / i j s m s-v 4 i 4 p 111}$

Volume: 4 Issue: 4

July to August 2021

https://www.ijsmsjournal.org

teaching, learning methods and emotional factors affecting foreign language learning. Her hobbies are listening to music and watching movie.

\section{References}

[1] Abrar, M., Mukminin, A., Habibi, A., Asyrafi, F., Makmur, M., \&Marzulina, L. (2018). “If our English isn't a language, what is it? ’'Indonesian EFL Student Teachers' Challenges Speaking English. The Qualitative Report, 23(1), 129-145.

[2] Al Ruhaily, A. R. S. \&Badr, S. A. M. (2011).The Effectiveness of a Suggested Program Based on Using Oral Communicative Activities in Developing EFL Students' Speaking Proficiency and their Attitude Towards it. University of Taibah, ElMadinaELmonwra, Saudia, Unpublished Master Thesis.

[3] Ashour, J. M. (2014). The Effect of Using a Videoconferencing-based Strategy on UNRWA 9th Graders' English-Speaking Skills and their Attitudes towards Speaking. The Islamic University of Gaza, Gaza, Palestine, Unpublished Master Thesis.

[4] Chaney, M., \& Burk, S. (1998). Foreign Language Testing: A Practical Approach. Regents Publishing Company, Inc., 2 Park Ave., New York, NY 10016

[5] Durkheim, E. (1956). The evolution and the role of secondary education in France. In Education and Sociology (pp. 135 - 153). New York: The Free Press.

[6] Farangi, M. R., Nejadghanbar, H., Askary, F., \&Ghorbani, A. (2015).The Effects of Podcasting on EFL Upper-Intermediate Learners' Speaking Skills. CALL, 16(2), 1-18

[7] Gay, G.; M. Stefanone, M. Grace-Martin, \& H. Hembrooke.(2001) "The effects of wirelessComputing in collaborative learning environments". International Journal of Human- Computer Interaction, 13(2), pp. 257-276.

[8] Ghoneim, N. M. M., \&Elghotmy, H. E. A. (2016).A Suggested Project to Develop EFL Teaching in the Egyptian Universities in the Light of Knowledge Economy Investing in ELT Innovation. English Language Teaching, 9(4), 139.

[9] Greenbaum, J. \& Nelson, L (1996): A place called school. New York: McGraw-Hill.

[10] Hamdani, D. S. A. (2013). Mobile learning: A good practice. Procedia - Social and Behavioral Sciences 103:665-74.

[11] Hwang, W.-Y., Huang, Y.-M., Shadiev, R., Wu, S.-Y., \& Chen, S.-L.(2014). Effects of using mobile devices on English listening diversity and speaking for EFL elementary students.Australasian journal of educational technology, 30(5).

[12] Keengwe, J, \&Bhargava, M. (2013).Mobile learning and integration of mobile technologies in education.Education and Information Technologies. 19(4):737-46.

[13] Kitsantas, A., \&Dabbagh, N. (2010).Learning to Learn with Integrative LearningTechnologies (ILT): A practical guide for academic success. Greenwich, CT: Information Age Publishing.

[14] Kline, J. A. (1989). Speaking Effectively: A Guide for Air Force Speakers. AIR UNIV MAXWELL AFB AL.

[15] Koole.M. (2009). “A model for framing mobile learning.” In M. Ally (Ed.), Mobile learning: Transforming the delivery of education $\&$ training, pp. 25-47. Athabasca: AU Press.

[16] Kukulska-Hulme A. and L. Shield. (2008). "An Overview of Mobile Assisted LanguageLearning: Can Mobile Devices Support Collaborative Practice in Speaking andlistening?" http://portal.acm.org/citation.cfm?id=1520087 accessed Jul. 2009.

[17] Kramarski, B. \&Gutman, M. (2006).How can self-regulated learning be supported in mathematical E-learning environments? Journal of Computer Assisted Learning, vol. 22, no. 1, pp. 24-33.

[18] Lackman, K. (2010). Activities for improving speaking. England: United Kingdom Educational consultants.

[19] Lo'pez-Morteo, G. \& Lopez-Mariscal, G. (2007).An electronic ludic learning environment for mathematics based on learning objects. World Conference on Educational Multimedia, Hypermedia and Telecommunications (pp. 849- 852), 2003(1).

[20] Maryam, B., and Reza, O. (2014).Technology in Teaching Speaking Skill, Acme International Journal of Multidisciplinary Research, Vol. 2, Issue 4, pp. 9-13.

[21] Northover, M., \& Donald, C. (2001).The development of online learning in the UNITEC-same environment, new landscape. In Meeting at the Crossroads: Proceedings 18th ASCILITE Conference, pp. 443-451. 
DOI: $\underline{10.51386 / 25815946 / i j s m s-v 4 i 4 p 111}$

Volume: 4 Issue: 4
July to August 2021 https://www.ijsmsjournal.org

[22] Ormrod, J. E. (2000). Educational psychology: Developing learners. Upper Saddle River, NJ: Merrill

[23] Purpura, R. L. (2013).Teaching Speaking Strategies: What every teacher should know. New York, NY: Newbury House.

[24] Qureshi, I. A. (2012).The Importance of Speaking Skills for EFL Learners. Pakistan: AlamaIqbal Open University.

[25] Richards, C. (2008). Theories of teaching in language teaching.InJ. C. Richards and W. A. Renandya (Eds), Methodology in language teaching: An anthology of current practice (pp.19-25). Cambridge: Cambridge University Press.

[26] Rizqiningsih\&Hadi, (2019).The Study of Language: An Introduction, $4^{\text {th }}$ ed., (Cambridge: Cambridge University, 2010$)$, p.81.

[27] Sung, Y. T., Chang, K. E. \& Liu, T. C. (2016).The effects of integrating mobile devices with teaching and learning on students' learning performance: A meta-analysis and research synthesis." Computers and Education, 94. 252- 75.

[28] Widiastuti, R. (2008). Teaching Speaking through dialogue to the eleventh year student: a case study at SMK Muhammadiyah 1 JATINOM. UniversitasMuhammadiyah Surakarta.

[29] Yang Soon.G. (2005). “Technology for Foreign Learning. 'http://www.readingmatrix.com/conference/pp/proceedings/gohyingsoon.pdf, accessed Dec 2010.

[30] Yiping, W. \& Lei, W. (2010).The practice of student-centered teaching mode.from: http://wenku.baidu.com/link?url=uMkwOzGDsNrIpW9IuPVxjxryymPaJAPLKQcCYNvQn_qN4wPhCrsz52v3fpn5xx3kufZvDIdUD WFizFllM0ERbZM9ohRnEdPJU8MDXIPrrG

[31] Zaremba, K., Shamsaee, S. (2006). Viability of construct validity of the speaking modules of international language examinations (IELTS vs. TOEFL iBT): evidence from Iranian test-takers. EducAsseEvalAcc 24, 263-277 https://doi.org/10.1007/s11092-0119137-Z

[32] Zhang, J. A. (2009). Speaking Effectively: A Guide for Air Force Speakers. AIR UNIV MAXWELL AFB AL 